Jurnal Kajian Bimbingan dan Konseling

Vol 1, No. 1, 2016, hlm. 7-11

Tersedia Online di http://journal.um.ac.id/index.php/bk

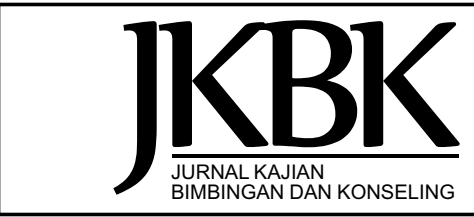

\title{
KEEFEKTIFAN KONSELING KELOMPOKADLER UNTUK MENINGKATKAN KETERAMPILAN INTERPERSONAL SISWA SMP
}

\author{
Mega Rahma Fitriani, Nur Hidayah \\ Bimbingan dan Konseling-Fakultas Ilmu Pendidikan-Universitas Negeri Malang-Jl. Semarang No. 5 Malang \\ E-mail:mega.rahma1834@gmail.com
}

\begin{abstract}
Interpersonal skills is one of the skills that must be owned by a person in a relationship with other people. A person who failed in developing their interpersonal skills will be found difficulty in many aspects their life, especially on their social aspects. The purpose of this study is to know the effectiveness of Adler group counseling for improving interpersonal skills of junior high school students. This type of study is an quasi experimental method and program of study interrupted time series. From the result of hypotheses which is using wilcoxon signed ranks test, it is concluded if Adler group counseling affective to improving interpersonal skills of junior high school students.
\end{abstract}

Keywords: Adler group counseling; interpersonal skills; junior high school students

\begin{abstract}
Abstrak: Keterampilan interpersonal adalah salah satu keterampilan yang harus dimiliki seseorang dalam menjalin hubungan antarpribadi. Individu yang gagal dalam mengembangkan keterampilan interpersonalnya akan mengalami hambatan dalam berbagai aspek kehidupannya, terutama pada aspek sosialnya. Penelitian ini bertujuan untuk menguji keefektifan konseling kelompok Adler untuk meningkatkan keterampilan interpersonal siswa SMP. Jenis penelitian yang digunakan adalah quasi eksperimen dengan rancangan interrupted time series. Hipotesis yang diuji dengan wilcoxon signed ranks test menyimpulkan bahwa konseling kelompok Adler efektif untuk meningkatkan keterampilan interpersonal siswa SMP.
\end{abstract}

Kata kunci: konseling kelompok Adler; keterampilan interpersonal; siswa SMP

Usia rata-rata siswa Sekolah Menengah Pertama (SMP) berada pada tahap perkembangan masa puber. Perubahan yang terjadi pada proporsi tubuh berpengaruh pada kondisi psikologis remaja. Perubahan tersebut akan terlihat dari sikap dan perilaku anak dalam berhubungan dengan orang lain. Keterampilan interpersonal adalah kemampuan individu berhubungan dengan orang lain.

Sukmadinata (2007:125) menunjukkan perilaku sosial sesuai harapan masyarakat, serta memiliki rasa tanggung jawab bagi kemajuan dan kesejahteraan bersama. Namun, tidak jarang para remaja sulit menerima perubahan, sehingga mereka mengalami masalah pada penyesuaian sosial. Agar individu dapat diterima di lingkungan sosial, diperlukan sebuah keterampilan. Salah satu keterampilan yang harus dimiliki dalam membina hubungan dengan orang lain adalah keterampilan interpersonal.

Menurut Johnson (2009:8) keterampilan interpersonal adalah kemampuan seseorang berinteraksi dengan orang lain secara efektif. Keterampilan interpersonal merupakan dasar seseorang untuk memulai suatu hubungan sosial yang tepat, yaitu bagaimana memahami reaksi seseorang dan memberikan respon yang tepat. 
Menurut Safaria (2005), keterampilan interpersonal menjadi penting karena pada dasarnya manusia tida $k$ bisa hidup sendiri. Banyak kegiatan dalam hidup seseorang yang terkait dengan orang lain. Individu yang gagal mengembangkan kemampuan interpersonalnya, maka ia akan mengalami banyak hambatan terutama di dunia sosialnya. Akibatnya mereka tersisihkan dan tidak mendapat peran penting dalam kehidupan sehingga merasa kesepian, tidak berharga, mengisolasi diri dan lebih parah lagi jika sampai tahap depresi.

Siswa yang memiliki social interest yang rendah menunjukkan gejala-gejala seperti jarang bergaul dengan teman-teman di kelas, jarang dikenal teman-teman kelasnya, lebih sering menunjukkan sikap menyendiri, monoton, pasif dan kurang menonjol dalam segala hal, tidak hanya berpengaruh terhadap pergaulan, tetapi juga berpengaruh pada proses belajar dan motivasi belajar siswa rendah.

Layanan konseling di dalam bimbingan dapat digunakan untuk membantu siswa dalam meningatkan keterampilan interpersonal. Pemberian konseling kelompok bertujuan untuk meningkatkan kepercayaan diri konseli, melatih konseli berpikir positif, melatih komunikasi, dan berlatih mengendalikan perasaan diri. Dengan menggunakan konseling kelompok dan memanfaatkan dinamika kelompok, anggota akan lebih mudah menyampaikan keluhan, saling berbagi, dan membantu sesama anggota kelompok menggunakan dinamika kelompok.

Pendekatan konseling yang sesuai untuk meningkatkan keterampilan interpersonal adalah konseling kelompok Adler. Pendekatan ini menekankan pada peningkatan social interest seseorang yang memungkinkan siswa meningatkan daya juang dan social interest dalam mencapai superioritas sesuai dengan kemampuannya. Dengan demikian siswa diharapkan memiliki keterampilan interpersonal yang diperlukan untuk menjalin hubungan antarpribadi. Berdasarkan uraian tersebut keefektifan konseling kelompok Adler untuk meningkatkan keterampilan interpersonal siswa SMP perlu diteliti.

\section{METODE}

Desain penelitian yang digunakan adalah time series design, dengan variasi interrupted time series design (Creswell, 2012:315). Peneliti menggunakan rancangan penelitian ini dengan alasan bahwa penelitian yang dilakukan dengan pengukuran yang dilakukan berulang-ulang, hanya menggunakan satu kelompok eksperimen (tanpa kelompok kontrol) dan penentuan sampel tidak dapat dipilih secara random (Sugiyono, 2009:74).

Untuk mengetahui perbedaan tingkat keterampilan interpersonal siswa, digunakan inventori keterampilan interpersonal. Inventori keterampilan interpersonal diuji coba di dua kelas, yaitu kelas VII C dan VII E di SMP Laboratorium UM. Nantinya inventori keterampilan interpersonal ini digunakan peneliti dalam melakukan pengukuran. Untuk mengetahui adanya pengaruh suatu tindakan terhadap suatu variabel, dilakukan pengukuran awal (pre-test) dan pengukuran setelah pemberian treatment (post-test) masing-masing sebanyak tiga kali.

Penelitian ini mengambil subjek penelitian pada siswa SMP kelas VII di SMP Laboratorium UM. Subjek penelitian ditetapkan di kelas VII A, B, D dan F. Peneliti mengambil empat kelas tersebut karena ingin mengetahui populasi siswa yang memiliki keterampilan interpersonal rendah atau sedang di kelas VII SMP Laboratorium UM, kecuali kelas VII C dan E yang sudah digunakan untuk uji coba instrumen.

Sebelum memberikan treatment konseling kelompok Adler, terlebih dahulu peneliti melancarkan pretest kepada empat kelas untuk mengetahui kelompok siswa yang memiliki keterampilan interpersonal yang rendah atau sedang. Empat kelas dari kelas VII yaitu kelas VII A, B, D dan F berjumlah 147 siswa menunjukkan bahwa tidak ada siswa yang memiliki keterampilan interpersonal rendah. Diperoleh 82 siswa yang memiliki keterampilan interpersonal sedang.

Setelah mengetahui kelompok siswa yang memiliki keterampilan interpersonal sedang, peneliti melancarkan pre-test sebanyak tiga kali kepada kelompok tersebut. Hasil analisis dari data pre-test sebanyak tiga kali yang dilakukan oleh peneliti, diperoleh 16 siswa yang memiliki skor tiga kali pre-test yang konsisten. Setelah diketahui kekonsistenannya, lima subjek penelitian ditentukan dengan menggunakan teknik sampling purposive yaitu pengambilan subjek penelitian dari populasi yang dilakukan dengan pertimbangan tertentu (Sugiyono, 2009:85). Cara ini dilakukan bila anggota populasi dianggap homogen. Seperti pada penelitian ini, 
populasinya homogen yaitu siswa yang memperoleh skor pada kriteria sedang dari inventori keterampilan interpersonal, adalah siswa yang memiliki keterampilan interpersonal sedang.

Setelah memperoleh lima subjek penelitian, peneliti memberikan treatment yaitu konseling kelompok Adler sebanyak lima kali pertemuan. Panduan konseling dijadikan pedoman bagi peneliti ketika menjalankan treatment. Buku panduan yang digunakan telah melalui uji ahli, bertujuan untuk memperoleh kepastian bahwa panduan pelaksanaan konseling layak dan dapat digunakan sebagai panduan treatment dalam mencapai tujuan penelitian.

Setelah melaksanakan treatment, peneliti melaksanakan post-test yang dilakukan tiga kali. Tujuan dari diadakannya post-test untuk mengetahui konsistensi peningkatan skor keterampilan interpersonal siswa setelah diberi treatment. Selain itu, post-test juga sebagai kegiatan follow up dari treatment yang telah dilakukan oleh peneliti.

Analisis data menggunakan analisis grafis, analisis data inferensial nonparametrik dan analisis data deskriptif. Analisis grafis bertujuan untuk mempermudah pembaca melihat peningkatan skor pre-test dan post-test dari masing-masing subjek penelitian. Analisis data inferensial nonparametrik dalam penelitian ini yakni wilcoxon signed ranks test, uji ini bertujuan untuk mengetahui perbedaan rata-rata kelompok dan digunakan untuk membuktikan hipotesis sehingga diperoleh kesimpulan tentang masalah yang diuji. Uji wilcoxon signed ranks test digunakan karena berdistribusi tidak normal, yaitu subjek penelitian kurang dari 30 orang. Sedangkan analisis data deskriptif yaitu data pendukung berupa hasil pengamatan secara langsung dan catatan perkembangan konseli yang dianalisis dengan deskriptif oleh peneliti bertujuan untuk melihat kemajuan keterampilan interpersonal yang dimiliki oleh siswa.

\section{HASIL DAN PEMBAHASAN}

Layanan konseling kelompok Adler digunakan untuk membantu meningkatkan kepercayaan diri konseli, melatih konseli berpikir positif, melatih komunikasi, dan berlatih mengendalikan perasaan diri. Konseling kelompok Adler merupakan layanan yang betujuan untuk meningkatkan keberanian, mengurangi perasaan inferior dan mendorong berkembangnya minat sosial (Alwisol, 2006:98).

Konseling kelompok memudahkan anggota dalam menyampaikan keluhan, saling berbagi, dan saling membantu sesama anggota kelompok dengan adanya dinamika kelompok. Dinamika kelompok merupakan suasana yang hidup dan bergerak karena keaktifan interaksi antar anggota yang berkembang (Prayitno, 2004:309). Perilaku dapat muncul melalui proses belajar, dan konseling kelompok Adler merupakan salah satu media belajar individu untuk memahami perilakunya yang kurang tepat.

Konseling kelompok Adler yang dilakukan lima kali pertemuan dengan selang waktu satu hari kecuali hari minggu. Panduan konseling dijadikan pedoman bagi peneliti ketika menjalankan treatment. Kegiatan dan tahap-tahap yang ada di setiap sesi pertemuan konseling dilaksanakan sesuai dengan panduan konseling kelompok Adler. Dari pre-test yang dilakukan tiga kali diketahui terdapat lima orang siswa memiliki skor keterampilan interpersonal dengan kategori sedang dan konsisten. Dikatakan konsisten, jika skor yang dihasilkan siswa bertambah atau berkurang $\leq 4$ skor dalam tiga kali pre-test. Setelah subjek diberi treatment sebanyak lima kali, kemudian dilakukan tiga kali post-test kepada lima siswa. Hasilnya terdapat peningkatan skor post-test yang dilakukan sebanyak tiga kali, dan berada pada kategori memiliki keterampilan interpersonal tinggi.

Hipotesis dinyatakan diterima jika signifikansinya $<0,05$. Perhitungan uji wilcoxon signed ranks test dalam penelitian ini diperoleh signifikansinya 0,042 , kurang dari 0,05 sehingga $\mathrm{H}_{\mathrm{o}}$ ditolak. Dari uji hipotesis, dapat dikatakan bahwa terdapat peningkatan tingkat keterampilan interpersonal sebelum dan sesudah diberi treatment berupa konseling kelompok Adler selama lima kali pertemuan, yang ditunjukkan dari skor posttest yang lebih tinggi dari pada skor pre-test. Berdasarkan skor pre-test dan post-test masing-masing siswa dari kelompok eksperimen dan hasil uji hipotesis menggunakan wilcoxon signed ranks test, dapat dikatakan bahwa konseling kelompok Adler efektif untuk meningkatkan keterampilan interpersonal siswa SMP.

Perubahan keterampilan interpersonal siswa dalam kelompok eksperimen dapat dilihat dari keberanian dan keaktifan siswa yang meningkat. Pada awal pertemuan, konseli cenderung malu, canggung dan ragu mengemukakan pendapat. Namun, dengan permainan sederhana di setiap awal sesi pertemuan dan suasana 
yang membuat konseli bisa lebih nyaman, mampu merubahan sikap mereka yang dapat ditunjukkan dari mereka yang aktif bertanya dan memberi masukan kepada anggota kelompok yang lain selama mengikuti proses treatment. Hal ini menandakan bahwa konseli mengalami peningkatan percaya diri dan keberanian dalam setting sosial yaitu kelompok.

Konseli merasakan manfaat konseling Adler ini dalam kehidupannya sehari-hari baik di lingkungan sekolah maupun lingkungan di rumah. Mereka menyampaikan perasaannya pada lembar tugas dan lembar kemajuan konseli yang ditulis konseli pada setiap pertemuan. Kemajuan lainnya diperoleh dari sikap konseli yang mulai berani berbaur dan lebih terbuka dengan teman yang sebelumnya tidak akrab, menjadi tempat orang lain bercerita dan menjaga rahasia, berani berpendapat di dalam kelompok maupun di dalam kelas, bertanya jika belum jelas dan menghargai teman serta mampu menyelesaikan konflik dengan orang lain. Hal ini sesuai dengan aspek keterampilan interpersonal dari Johnson, dimana aspek satu dengan aspek lainnya saling berhubungan satu sama lain. Ketika konseli memiliki keyakinan dalam diri dan cara pandang sesuatu yang lebih baik, maka konseli akan dengan mudah mengembangkan interest social dan keterampilan interpersonal di dalam lingkungan sosialnya.

Kemajuan konseli sangat sesuai dengan tujuan konseling kelompok, yaitu untuk meningkatkan kepercayaan diri konseli, melatih konseli berpikir positif, melatih komunikasi, dan berlatih mengendalikan perasaan diri. Dengan menggunakan konseling kelompok, anggota akan lebih mudah menyampaikan keluhan, saling berbagi, dan membantu sesama optimis, ego pribadi kemandirian. Sedangkan sikap individualistik mengakibatkan emosi seseorang labil, ketidakpercayaan diri, sulit bersosialisasi dan menarik diri dari lingkungan.

Hasil penelitian ini sejalan dengan hasil penelitian Maknun (2012) yang menemukan bahwa konseling kelompok Adler dapat meningkatkan rasa percaya diri siswa. Selain itu, penelitian Ramadani dan Hariastuti (2015:7), menyebutkan bahwa konseling kelompok Adler dapat mengurangi rasa rendah diri siswa. Hal ini lebih menguatkan bahwa konseling kelompok Adler memfokuskan pemahaman konseli terhadap kemampuan yang mereka miliki. Perasaan inverioritas berkurang, muncul rasa percaya diri dan menumbuhkan motivasi dalam diri siswa.

Perubahan yang terjadi pada siswa yang mendapat treatment berupa konseling kelompok Adler mengalami perubahan pola pikir pada tahap reedukasi. Siswa mulai memiliki pemahaman baru terhadap diri dan lingkungannya. Melalui pemberian tugas dan pemanfaatan dinamika kelompok dalam konseling dapat mengembangkan rasa percaya diri dan interest social siswa. Dengan demikian perasaan inverior siswa berkurang karena mereka menyadari kemampuan yang mereka miliki sehingga mampu memotivasi diri untuk mencapai superioritas. Dengan meningkatnya interest social siswa, maka keterampilan interpersonal mereka juga meningkat. Dari hasil temuan penelitian tersebut dan didukung oleh penelitian sebelumnya, dapat menguatkan bahwa konseling kelompok Adler efektif untuk meningkatkan keterampilan interpersonal siswa SMP.

\section{SIMPULAN DAN SARAN}

\section{Simpulan}

Pada penelitian ekeperimen di SMP Laboratorium UM ini diketahui adanya perbedaan skor keterampilan interpersonal antara sebelum dan sesudah pelaksanaan treatment. Skor post-test yang mengalami peningkatan dari skor pre-test, menunjukkan bahwa siswa yang memiliki keterampilan interpersonal sedang, dapat ditingkatkan dengan pemberian treatment berupa konseling kelompok Adler. Akhirnya dapat disimpulkan bahwa konseling kelompok Adler efektif untuk meningkatkan keterampilan interpersonal siswa SMP.

\section{Saran}

Berdasarkan hasil penelitian, pembahasan, dan kesimpulan yang telah dikemukakan, ada saran-saran pada beberapa pihak sebagai tindak lanjut penelitian ini. Para konselor dapat membantu siswa SMP meningkatkan keterampilan interpersonal menggunakan panduan konseling kelompok Adler yang telah disusun 
peneliti. Peneliti selanjutnya, yaitu: (1) dapat menggunakan desain penelitian yang berbeda, (2) menguji keefektifan panduan eksperimen konseling kelompok Adler dan memperbaiki panduan melaui PTB (Penelitian Tindakan Bimbingan), dan (3) meneliti keefektifan konseling kelompok Adler dengan variabel terikat yang lain, misalnya untuk meningkatkan efikasi diri siswa.

\section{DAFTAR RUJUKAN}

Alwisol. 2006. Psikologi Kepribadian: Edisi Revisi. Malang: UMM Press.

Creswell, John W. 2012. Educational Research Planning, Conducting, and Evaluating Quantitative and Qualitative Research: Fourth Edition. Boston: Pearson Education.

Johnson, David W. 2009. Reaching Out: Interpersonal Effectiveness and Self Actualization: Tenth Edition. New Jersey: Pearson Education.

Maknun, Lu'lu'il. 2012. Penerapan Layanan Konseling Kelompok Pendekatan Adlerian untuk Meningkatkan Rasa Percaya Diri saat Menghadapi Ujian Akhir Semester pada Siswa Kelas VIII-E SMP Negeri 16 Surabaya. (Skripsi Online), (http://luluciwheiwa.blogspot.com/2012/07/ penerapan-layanan-konseling-kelompok.html?m=1 diakses 14 Maret 2015).

Johnson, Frank P. \& Johnson, David W. 2012. Dinamika Kelompok Teori dan Keterampilan. Jakarta: Indeks.

Ramadani, M. F. \& Hastuti, R. T. 2015. Penerapan Konseling Kelompok Adler untuk Menguragi Sikap Rendah Diri kelas XI-IA2SMA Negeri Driyorejo Gresik. Jurnal UNESA. (Online). (http://dokumen.tips/ documents/penerapan-konseling-kelompok-adlerian-untuk-mengurangi-sikap-rendah-diri-kelas.html, diakses 15 Januari 2016).

Safaria, T. 2005. Interpersonal Intelegence: Metode Pengembangan Kecerdasan Interpersonal Anak. Yogyakarta: Amara Books.

Sugiyono. 2009. Metode Penelitian Kuantitatif dan Kualitatif dan R \& D. Bandung: Alfabeta.

Sukmadinata, Nana Syaodih. 2007. Landasan Psikologi Proses Pendidikan. Bandung: PT Remaja Rosdakarya. 